\title{
Spedbarnets størrelse påvirker dødeligheten
}

De som er født små, har høyere risiko for å dø av hjerte- og karsykdom som voksne. Det gjelder både jentebarn og guttebarn. Høy fødselsvekt hos gutter er assosiert med økt risiko for å dø av kreft som voksen.

Årsakene til hjerte- og karsykdom og kreft er sammensatte. Tidligere forskning har vært rettet mot risikofaktorer som kosthold, overvekt og røyking. Det viser seg nå at fødselsvekt og ernæring i fosterlivet også kan ha betydning.

- Vi har gjort en metaanalyse hvor vi har gått gjennom alle studier om temaet publisert i perioden 1966-2010. Resultatene viste at små nyfødte har lavere forventet levetid på sikt, sier Kari Ravndal Risnes.

- De med fødselsvekt $<3 \mathrm{~kg}$ hadde $13 \%$ høyere mortalitet enn de med fødselsvekt 3-4 kg. Lav fødselsvekt var spesielt knyttet til høyere risiko for hjerte- og kardødelighet $-12 \%$ økt risiko per kilo lavere fødselsvekt. For menn var høy fødselsvekt knyttet til økt dødelighet av kreft - $13 \%$ økt risiko per kilo høyere fødselsvekt. Vi kan ikke utelukke at f.eks. overvekt, svangerskapsforgiftning eller fødsel før termin kan ha påvirket resultatene, sier Risnes.
Hun har også analysert data fra fødejournaler fra nesten 40000 kvinner og menn født ved E.C. Dahls fødestiftelse i perioden 1920-60 og har koblet opplysningene til Dødsårsaksregisteret.

- Vi fant økt dødelighet av hjerteinfarkt hos dem som hadde liten hodeomkrets ved fødselen, særlig hvis moren var høy. Dødeligheten av hjerte- og karsykdom var også økt dersom morkakevekten var høy i forhold til barnets vekt, spesielt gjaldt dette store nyfødte. Morkakevekten er ofte høy hvis kvinnen har diabetes, anemi, er overvektig eller har dårlig ernæringstilstand. Dette indikerer at morkakens funksjon har betydning for barnets risiko for hjerte- og karsykdom, sier Risnes.

\section{Anne Forus}

anne.forus@hotmail.com

Tidsskriftet

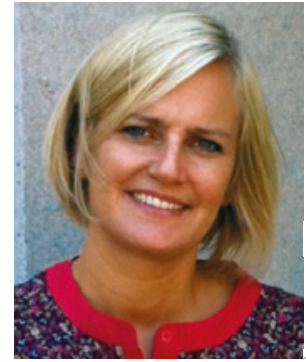

Kari Ravndal

Risnes.

Foto privat

Disputas

Kari Ravndal Risnes disputerte for ph.d.-

graden ved Norges teknisk-naturvitenskaplige universitet 23.9. 2011. Tittelen på avhandlingen er Birth size and adult mortality: a systematic review and a long-term follow-up of nearly 40000 individuals born at St Olav University Hospital in Trondheim from 1920 to 1960.

\section{Farlig å fly?}

\section{Flyreiser påvirker pasienter med lungesykdom i den grad at det kan være nødvendig med oksygentilskudd under reisen.}

Under flyreiser er lufttrykket $\mathrm{i}$ kabinen lavere enn på bakken. Dette medfører at oksygeninnholdet i blodet faller, og hos passasjerer med lungesykdom kan det bli så lavt at oksygentilskudd under reisen er anbefalt. Det viser avhandlingen til lege og forsker Aina Akerø ved Lungemedisinsk avdeling, Oslo universitetssykehus, Ullevål.

Hun har studert hvordan flyreiser påvirker pasienter med kronisk obstruktiv lungesykdom (kols). Resultatene er brukt som grunnlagsmateriale i nye internasjonale retningslinjer for vurdering av pasienter med kols som skal reise med fly.

- I en spørreundersøkelse fant vi at over halvparten av et utvalg norske pasienter hadde fløyet i løpet av en toårsperiode. En firedel hadde hatt plagsomme symptomer under reisen. Risikoen for pusteproblemer hos disse var sjudoblet sammenliknet med risikoen for slike problemer hos friske, sier Akerø.
- Under en reise til Gran Canaria så vi at oksygenmetningen hos kolspasientene var betydelig lavere enn den var på bakken, og at metningen falt ytterligere når de gikk omkring i flyet. Tilsvarende funn ble gjort ved simulerte flyreiser hvor pasienten pustet inn en gass med oksygeninnhold svarende til luften i en flykabin og i lavtrykkskammer, forteller Akerø.

På bakgrunn av disse funnene har Akerø konsentrert seg om hvordan man kan forutsi hvem som trenger å ha med seg oksygenflasker om bord og hvem som kan reise uten. Med tanke på dem som må ha med seg oksygen om bord, dokumenterer Akerø også hvilke typer oksygentilførsel som egner seg for bruk under flyreiser.

\section{Tone Bergset}

tone.bergset@legeforeningen.no

Tidsskriftet

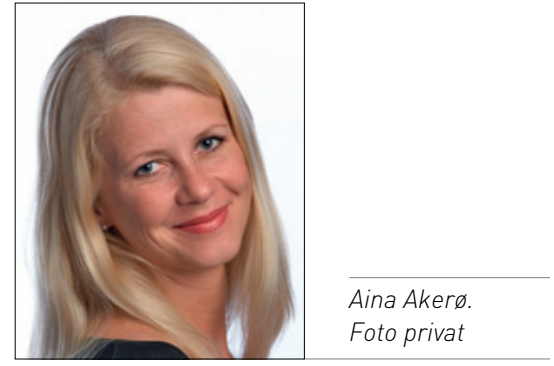

Disputas

Aina Akerø disputerte for ph.d.-graden ved Det medisinske fakultet, Universitetet i Oslo, 11.10. 2011 med avhandlingen Effects of air travel on patients with COPD. 